\title{
Morphology and ecological setting of the basal echinoid genus Rhenechinus from the early Devonian of Spain and Germany
}

Andrew B. Smith, Mike Reich, and Samuel Zamora

Acta Palaeontologica Polonica 58 (4), 2013: 751-762 doi: http://dx.doi.org/10.4202/app.2011.0098

Based on new material from Germany and Spain, the echinoid "Lepidocentrus" ibericus from the Early Devonian (Emsian) of northern Spain is shown to be congeneric with Rhenechinus from the Hunsrück Slate of south-western Germany. New information on the lantern, pedicellariae and internal structure of the theca is provided, and confirms this genus as a member of the Echinocystitidae-Proterocidaridae clade and the most primitive of all Devonian echinoids. The two environmental settings in which Rhenechinus is found are very different: the Spanish specimens come from a relatively shallow-water bryozoan meadow setting while the German specimens are preserved in a deep-water setting. We deduce that the rare echinoid specimens from the Hunsrück Slate are all allochthonous, whereas the Spanish material is preserved in situ.

Key words: Echinodermata, Echinoidea, morphology, phylogeny, Devonian, Spain, Germany.

Andrew Smith [a.smith@nhm.ac.uk] and Samuel Zamora [samuel@unizar.es], Department of Palaeontology, The Natural History Museum, Cromwell Road, London SW7 5BD, UK; Mike Reich [mreich@gwdg.de], Geowissenschaftliches Zentrum der Universität Göttingen, Museum, Sammlungen \& Geopark, Goldschmidtstr. 1-5, D-37077 Göttingen, Germany.

This is an open-access article distributed under the terms of the Creative Commons Attribution License (for details please see creativecommons.org), which permits unrestricted use, distribution, and reproduction in any medium, provided the original author and source are credited. 
